\title{
Evaluation of Some Rabi Crops during Winter Season in Terai Region of West Bengal, India
}

\author{
Koushik Roy ${ }^{1 *}$, Ashim Chandra Sinha ${ }^{2}$ and Partha Sarathi Patra ${ }^{3}$ \\ ${ }^{I}$ Rigional Research Station (Hill Zone), Uttar Banga Krishi Viswavidyalaya, India \\ ${ }^{2}$ Department of Agronomy, Uttar Banga Krishi Viswavidyalaya, India \\ ${ }^{3}$ Regional Research Station (Terai zone), Uttar Banga Krishi Viswavidyalaya, India \\ *Corresponding author
}

\section{A B S T R A C T}

\begin{tabular}{|l|}
\hline Ke y w or d s \\
$\begin{array}{l}\text { Rapeseed equivalent } \\
\text { yield, net return, B: C } \\
\text { ratio }\end{array}$ \\
\hline Article Info \\
\hline $\begin{array}{l}\text { Accepted: } \\
\text { 20 May } 2018 \\
\text { Available Online: } \\
\text { 10 June 2018 }\end{array}$ \\
\hline
\end{tabular}

Keywords

Rapeseed equivalent , net return, B: C

Article Info

Accepted:

Available Online:

10 June 2018

\begin{abstract}
A field experiment was conducted during rabi season of 2009-2010 and 2010-2011 at the instructional farm of Uttar Banga Krishi Viswavidyalaya, Pundibari, Coochbehar, to find out the best performing rabi crops under terai region of West Bengal. Eight economically important different rabi season crops were taken. The pooled analysis data revealed that among all the different treatments (crops) used in this experiment. After harvesting of all the crops Harvest index (\%), rapeseed-equivalent yield (REY), gross return, net return and B: $\mathrm{C}$ ratio was calculated. Highest REY was recorded in fababean. Highest net return was recorded in wheat. Maximum B: C ratio was obtained in wheat. B: C ratio of buckwheat and rapeseed was at par with wheat. So it can be recommended to the farmers of terai region of West Bengal to grow rapeseed, wheat and buckwheat during winter season.
\end{abstract}

\section{Introduction}

The greatest challenge before the country during the 21st century is to produce enough food, fodder, fibre, fuel and raw materials for continuously increasing human and animal population. India needs 262 million tonnes of food grain to feed 1.30 billion populations by 2020 (Paroda, 1999). Production of rabi cereals and pulse is not increasing day by day as the area of rabi cereals is replaced by the rabi oilseed specially by rapeseed, due to its good production ability and market value. From farmers point of view it is logical to grow rapeseed in this area, keeping it in this mind an investigation was undertaken to study the performance of the rabi crops viz. cereals like wheat, buckwheat (pseudo-cereal), pulses like lentil, lathyrus and fababean, and oilseeds like mustard, linseed and niger with the objective to find out the best performing crop under terai region of west Bengal.

\section{Materials and Methods}

A field experiment was conducted during rabi season of 2009-2010 and 2010-2011 at the instructional farm of Uttar Banga Krishi Viswavidyalaya, Pundibari, Coochbehar, to study the performance of rabi crops under terai region of West Bengal. The experiment was laid out in Randomized Block Design (RBD) with 4 replications. The treatments (8) were T1: Wheat, T2: Buckwheat, T3: Lentil, 
T4: Grasspea, T5: Fababean, T6: Rapeseed, T7: Linseed and T8: Niger.

After maturity each crops were harvested. After harvesting dried grain and straws were weighed. Equivalent yield was calculated using conversion of monetary value. Let we have to compare between two crops $\mathrm{X}$ and $\mathrm{Y}$. Taking $X$ 's yield constant, we have to calculate $X$ 's equivalent yield of $Y$. So the formula is -

X's equivalent yield of $Y=\frac{\text { Yield of } Y(\text { in } \mathrm{kg}) \times \text { Price of } Y(R s . / \mathrm{kg})}{\text { Price of } X(R s . / \mathrm{kg})}$

Among the different crops grown during rabi season rapeseed is one of the most important main crops grown by the farmers which cover large area under terai region of West Bengal due to shorter in duration (matures within 9095 days after sowing) for which rapeseedequivalent yield (REY) was calculated.

The total cost of cultivation was calculated considering the expenditure on land preparation, seed material, sowing, soil treatment, inter-culture operations, irrigations, plant protection, harvesting, threshing etc. and the cost of manures and fertilizers as per treatments.

Gross return was calculated from the total output of all the main products and byproducts before deducting the cost of cultivation.

Net return was computed by deducting the total cost of cultivation from the total output of all the main products and byproducts.

Benefit: Cost ratio was computed by dividing the gross return with the cost of cultivation.

The recorded data were statistically analyzed following Gomez and Gomez (1983). All types of variable production cost are recorded to find out the benefit cost ratio (BCR)

\section{Results and Discussion}

Production of wheat grain and straw yield $(28.67 \mathrm{q} / \mathrm{ha})$ was little bit lower than its potential yield as reported by Kaur and Dhaliwal (2015) (Table 1). Grain yield of buckwheat was 11.19 q/ha. Kara (2014) has got similar type of result. Lentil yielded 9.59 $\mathrm{q} / \mathrm{ha}$, is a good production ability as per reported by DB et al., (2014).

Grasspea yielded (12.29 q/ha) satisfactorily as similar type of productivity has been reported by Larbi et al., (2010). Fababean showed great yield potentiality $(8.54 \mathrm{q} / \mathrm{ha})$ as per reported by Duc (1997). Rapeseed produced a good yield (11.34 $\mathrm{q} / \mathrm{ha})$ as at par yield has been reported by Kumar et al., (2018). Linseed production (10.02 q/ha) was also well as similar type of yield is reported by Andruszczak et al., (2015). Niger shows a little lower productivity $(9.62 \mathrm{q} / \mathrm{ha})$ than its full potentiality as per productivity reported by Jagtap et al., (2015).

Among all the crops, fababean recorded the highest Rapeseed-equivalent yield (REY) (12.98 $\mathrm{q} / \mathrm{ha})$ significantly during investigation which was significantly higher over to that of wheat (12.30 q/ha) and buckwheat (11.94 $\mathrm{q} / \mathrm{ha}$ ) followed by rapeseed (11.32 q/ha), lentil (10.96 q/ha), grass pea (10.16 q/ha), linseed $(8.12 \mathrm{q} / \mathrm{ha})$ and niger $(6.50 \mathrm{q} / \mathrm{ha})$ during the investigation (Table 2). Among the cereals including pseudo-cereal (buckwheat), highest REY was recorded in wheat followed by buckwheat during both the years of investigation.

Among the pulse crops, highest REY was recorded in fababean followed by lentil and grass pea during both the years of investigation. Similarly among the oilseed crops, highest REY was recorded in rapeseed followed by linseed and niger during both the years of investigation. 
Table.1 Grain/ Seed yield \& Straw yield and Harvest index of different crops (Pooled data of two years)

\begin{tabular}{|l|c|c|c|}
\hline Name of crops & Grain Yield (q/ha) & Straw Yield (q/ha) & Harvest index (\%) \\
\hline Wheat & 28.67 & 44.96 & 38.94 \\
\hline Buckwheat & 11.19 & 29.15 & 27.74 \\
\hline Lentil & 9.59 & 20.27 & 32.12 \\
\hline Grasspea & 12.29 & 22.42 & 35.41 \\
\hline Fababean & 8.54 & 22.86 & 27.20 \\
\hline Rapeseed & 11.34 & 26.31 & 30.12 \\
\hline Linseed & 10.02 & 28.00 & 26.35 \\
\hline Niger & 9.62 & 29.22 & 24.77 \\
\hline
\end{tabular}

Table.2 Rapeseed equivalent yield (REY) (q/ha) of different crops (pooled data of two years)

\begin{tabular}{|l|c|}
\hline \multicolumn{1}{|c|}{ Name of crops } & Rapeseed equivalent yield (q/ha) \\
\hline Wheat & 12.30 \\
\hline Buckwheat & 11.94 \\
\hline Lentil & 10.96 \\
\hline Grasspea & 10.16 \\
\hline Fababean & 12.98 \\
\hline Rapeseed & 11.32 \\
\hline Linseed & 8.12 \\
\hline Niger & 6.50 \\
\hline S.E.m $( \pm)$ & 0.10 \\
\hline CD $(\mathbf{P}=\mathbf{0 . 0 5})$ & 0.30 \\
\hline
\end{tabular}

Table.3 Economics of different crops (Pooled data of two years)

\begin{tabular}{|l|c|c|c|c|}
\hline Name of crops & $\begin{array}{c}\text { Cost of cultivation } \\
\left(\text { Rs. ha }^{-1}\right)\end{array}$ & $\begin{array}{l}\text { Gross return } \\
\left(\text { Rs. ha }^{-1}\right)\end{array}$ & $\begin{array}{l}\text { Net return } \\
\left(\text { Rs. ha }^{-1}\right)\end{array}$ & Benefit: Cost ratio \\
\hline Wheat & 20227.00 & 40582.00 & 20355.00 & 2.04 \\
\hline Buckwheat & 18027.00 & 36571.00 & 18544.00 & 2.02 \\
\hline Lentil & 18747.00 & 33562.50 & 14815.50 & 1.80 \\
\hline Grasspea & 18947.00 & 31800.50 & 12853.50 & 1.67 \\
\hline Fababean & 21221.00 & 39563.50 & 18342.50 & 1.89 \\
\hline Rapeseed & 16872.00 & 34961.50 & 18089.50 & 2.08 \\
\hline Linseed & 17284.00 & 26235.50 & 8951.50 & 1.54 \\
\hline Niger & 15961.00 & 21805.50 & 5844.50 & 1.37 \\
\hline S.E.m $( \pm)$ & 5.65 & 344.18 & 344.18 & 0.02 \\
\hline CD $(\mathbf{P}=\mathbf{0 . 0 5})$ & 17.16 & 1043.95 & 1043.95 & 0.06 \\
\hline
\end{tabular}


Among the cereals including pseudo-cereal (buckwheat), highest Gross return was recorded significantly in wheat followed by buck wheat during both the years of investigation. Among the pulse crops, highest Gross return was recorded significantly in fababean followed by lentil and grass pea during both the years of investigation. Similarly among the oilseed crops, highest Gross return was recorded significantly in rapeseed followed by linseed and niger during both the years of investigation (Table 3). Gross return (Rs. ha ${ }^{-1}$ ) was recorded to be maximum in case of wheat (Rs. 40,581.50) followed by fababean (Rs. 39,562.50), buckwheat (Rs. 36570.50), rapeseed (Rs. 34961.50), lentil (Rs. 33562.00), grass pea (Rs. 31799.50), linseed (Rs. 26235.00) and niger (Rs. 21804.50). It had also been found that the lowest gross return was achieved under niger during both the years of investigation (Table 3). The similar trend was also obtained in net return as found in gross return.

When benefit: cost ratio was taken into consideration, it was evident that among the pulse crops, highest benefit: cost ratio was recorded in fababean followed by lentil and grass pea during both the years of investigation. Similarly among the oilseed crops, highest benefit: cost ratio was recorded in rapeseed followed by linseed and niger during both the years of investigation (Table 3 ). The significantly highest benefit: cost ratio was recorded under rapeseed (2.08) followed by wheat (2.04) and buck wheat (2.02) among all the crops during that season and the lowest was observed in niger (1.37).

Highest Rapeseed Equivalent Yield (REY) was recorded in fababean followed by wheat, buckwheat, rapeseed, lentil, grasspea, linseed and niger during both the years of investigation. Highest net return was recorded in wheat followed by buckwheat, fababean, rapeseed, lentil, grasspea, linseed and niger during both the years of investigation. Maximum B: $\mathrm{C}$ ratio was obtained in wheat. $\mathrm{B}$ : $\mathrm{C}$ ratio of buckwheat and rapeseed was at par with wheat. So it can be recommended to the farmers of terai region of West Bengal to grow rapeseed, wheat and buckwheat and among the pulse crops fababean and lentil may be grown.

\section{References}

Andruszczak, S., Gawlik-Dziki, U., Kraska, P., Kwiecińska-Poppe, E., Różyło, K. and Pałys, E. (2015). Yield and quality traits of two linseed (Linum usitatissimum L.) cultivars as affected by some agronomic factors. Plant Soil Environ. Vol. 61, 2015, No. 6: 247-252.

DB, G., Darai, R., Subedi, S., Sarker, A. and Kumar, S. (2014). Grain Legumes in Nepal: Present Scenario and Future Prospects. World Journal of Agricultural Research, 2 (5), pp. 216222.

Duc, G. (1997). Faba bean (Vicia faba L.). Field Crops Research 53: 99-109.

Gomez, K.A. and Gomez A.A. (1983). Statistical procedure for Agric. Res. Published by John Wiley and sons, New York.

Jagtap, Prashant, K., Patel, M.C. (2015). Optimization of niger (Guizotia abyssinica L. CASS.) production under various resource constraints. Journal of Global Biosciences. Volume 4, Number 5, pp. 2315-2318.

Kara, N. (2014). Yield and Mineral Nutrition Content of Buckwheat (Fagopyrum esculentum Moench): The Effect of Harvest Times. Süleyman Demirel Üniversitesi Ziraat Fakültesi Dergisi 9 (1):85-94.

Kaur, S. and Dhaliwal, L.K. (2015). Yield and yield contributing characteristics of wheat under bed planting method. 
International Journal of Farm Sciences, 5(3) pp: 1-10.

Kumar, S., Patel, A., Nath, T., Verma, S. and Prajapati, A. (2018). Response of sulphur and zinc nutrition on growth, yield attributes and yields of rapeseed (Brassica napus L.) under upland soil of Vindhyan region. Journal of Pharmacognosy and Phytochemistry. SP1: 135-140.

Larbi, A., Abd El-Moneim, A.M., Nakkoul, H., Jammal, B. and Hassan, S. (2010).
Intra-species variations in yield and quality in Lathyrus species: 1. Grasspea (L. sativus L.). Animal Feed Science and Technology Volume 161, Issues 12, 13 October 2010, Pages 9-18.

Paroda, R.L. (1999). Towards sustainable agriculture export, New Paradigma, National Academy of Agricultural Science. In: Techniques and Manag. of Field Crops Production Ed. P. S. Rathore, p.2.

\section{How to cite this article:}

Koushik Roy, Ashim Chandra Sinha and Partha Sarathi Patra. 2018. Evaluation of Some Rabi Crops during Winter Season in Terai Region of West Bengal. Int.J.Curr.Microbiol.App.Sci. 7(06): 2545-2549. doi: https://doi.org/10.20546/ijcmas.2018.706.300 